DARK ADAPTATION IN MINERS With THEIR NUTRITIONAL STATE

\title{
A COMPARISON OF DARK ADAPTATION IN MINERS WITH THEIR NUTRITIONAL STATE
}

BY

\section{Dorothy Adams Campbell and Eva Tonks}

FROM THE RESEARCH DEPARTMENT OF THE BIRMINGHAM EYE HOSPITAL

A CAREFUL inquiry was made into the nutritional state of about 100 miners-i.e., their access to food, choice of diet, number in family, etc. In addition, estimations of plasma vitamin A and of carotene were undertaken to run parallel with the dark adaptation tests, to ascertain whether they were commensurate with the threshold value. The possibility of a deficiency in vitamin D was also considered, since miners working underground sweat heavily and are likely to lose surface fat, i.e., potential vitamin D. Moreover, they are rarely exposed to sunlight which favours the manufacture of vitamin $\mathrm{D}$, and the present day diet is unlikely to produce the required daily intake of $300-600$ I.U. of vitamin D. The estimation of plasma alkaline phosphate was taken as the indication of any possible deficiency of vitamin $\mathrm{D}$, while a liver function test was used as a check against the possibility that an abnormal vitamin $A$ content, or a raised blood phosphatase might be due to liver dysfunction.

The normal range for the blood constituents is as follows :-

$$
\begin{aligned}
& \text { Plasma caroteńe } \quad \ldots \quad \ldots \quad \ldots \quad 50-240 \mu \mathrm{g} \text { per } 100 \mathrm{ml} \text {. } \\
& \text { Vitamin A } \quad \ldots \quad \ldots \quad \ldots \quad \ldots \quad 70-140 \text { I.U. per } 100 \mathrm{ml} \text {. } \\
& \text { Alkaline phosphatase } \quad \ldots \quad \ldots \quad 5-10 \text { units per cent. }
\end{aligned}
$$

On analysis it was found that :-

(1) There was no parallelism between the threshold value and the level of vitamin $\mathrm{A}$ in the blood taken at the time of examination (either in surface or underground miners and in controls or in those with nystagmus). (See Tables I and II.)

(2) There was no significant variation in the plasma vitamin A or $D$ in comparison with age, occupation, or incidence of nystagmus. The plasma vitamin $A$ tends to be higher in nonminers and in miners working on the surface, than in those afflicted with nystagmus and in normal miners working underground (Table III).

(3) There was no evidence of any disturbance in liver function in the individuals tested (Table III).

(A) Owing to the system of rationing there was no seasonal variation in the dietary content of vitamin $A$, nor in the choice of diet available. 
TABLE I

Comparison of blood vitamin A level with threshold of dark adaptation surface workers

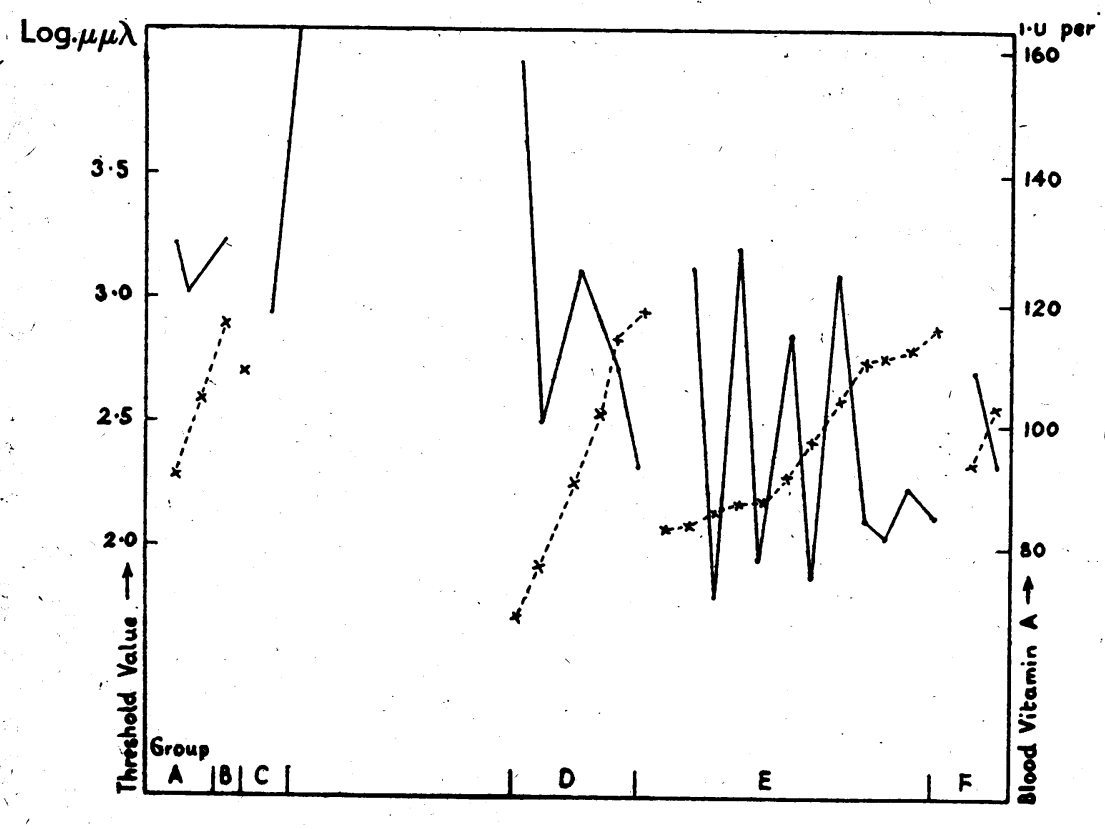

\section{TABLE II}

Comparison of blood vitamin A level with threshold of dark adaptation underground workers

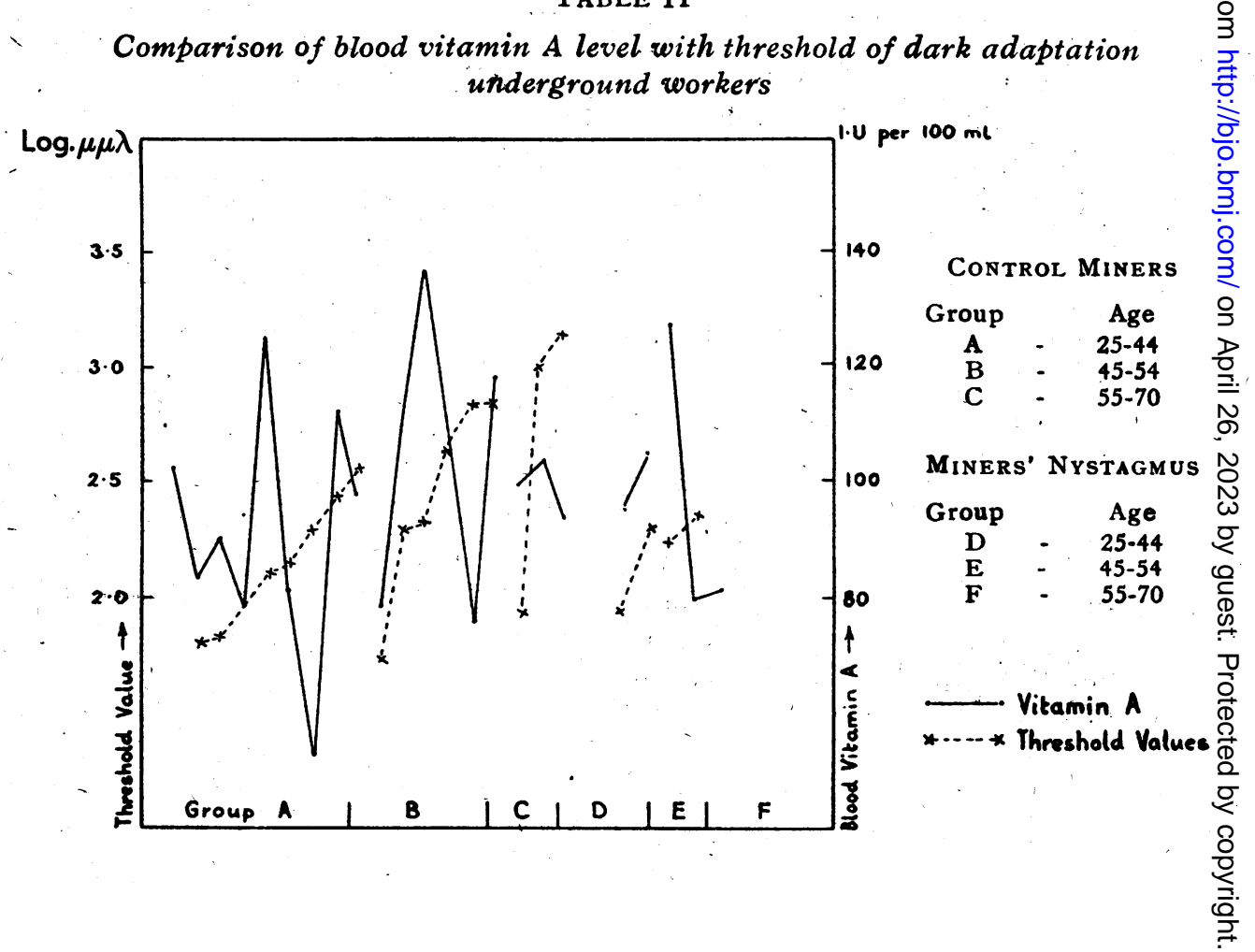

Control Miners

Group

Control Minerisi

Group Age $\vec{\rho}$

A : 25-44음.

C - 55-70

Miners' Nystagmigs

Group Age

D - 25-44?

F - $\quad 45-54-$

- Vitamin A

$x \cdots . . .-x$ Threshold Value 


\section{DaRk ADAPTATION IN Miners With THEIR}

Nutritional State

TABLE III. Biochemical Investigations classified in types of warker

Miners' Nystagmus : Underground workers

\begin{tabular}{l|c|c|c|c|c}
\hline $\begin{array}{c}\text { Age } \\
\text { Group }\end{array}$ & $\begin{array}{c}\text { Carotene } \\
\mu_{\mathrm{g}} \%\end{array}$ & $\begin{array}{c}\text { Vit. A. } \\
\text { I.U.\% }\end{array}$ & $\begin{array}{c}\text { Alk. Blood } \\
\text { Phosphatase } \\
\text { Units \% }\end{array}$ & $\begin{array}{c}\text { Liver } \\
\text { Function } \\
\text { Test Thymol } \\
\text { Turb. } \\
\text { ml. BaSo } \\
\text { susp. }\end{array}$ & $\begin{array}{c}\text { Threshold } \\
\text { Dark } \\
\text { Adaptation } \\
\text { Log. } \mu \mu \lambda\end{array}$ \\
\hline Under 25 & - & - & - & - & - \\
$25-44$ & $36(5)$ & $90(5)$ & $8 \% 1(2)$ & $0 \% 40(2)$ & $2 \%(2)$ \\
$45-54$ & $92(4)$ & $94(4)$ & $6 \% 3(2)$ & $0 \% 29(2)$ & $2 \% 59(3)$ \\
$55-70$ & $110(1)$ & $82(1)$ & - & - & $2 \% 21(1)$ \\
All ages & $65(10)$ & $91(10)$ & $7 \% 2(4)$ & $0 \% 35(4)$ & $2 \% 38(6)$
\end{tabular}

Miners' Nystagmus : Surface workers

\begin{tabular}{l|c|c|c|c|c} 
Under 25 & - & - & - & - & - \\
$25-44$ & $79(7)$ & $118(7)$ & $7 \cdot 3(4)$ & $0.27(3)$ & $2.37(8)$ \\
$45-54$ & $66(18)$ & $94(18)$ & $8.5(9)$ & $0.37(3)$ & $2.39(14)$ \\
$55-70$ & $69(6)$ & $93(6)$ & $9 \cdot 0(3)$ & - & $2.44(4)$ \\
All ages & $70(31)$ & $99(31)$ & $8.3(16)$ & $0.32(6)$ & $2.39(26)$
\end{tabular}

Control Miners : Underground workers

\begin{tabular}{l|c|c|c|c|c|c} 
Under 25 & $67(4)$ & $94(4)$ & $7 \cdot 2(2)$ & $0.35(2)$ & - \\
$25-44$ & $56(19)$ & $98(19)$ & $7 \cdot 3(11)$ & $0.33(10)$ & $2.12(9)$ \\
$45-54$ & $68(13)$ & $101(13)$ & $8 \cdot 8(6)$ & $0.40(5)$ & $2.47(6)$ \\
$55-70$ & $65(8)$ & $95(8)$ & $7 \cdot 9(4)$ & $0.49(4)$ & $2.71(3)$ \\
All ages & $62(44)$ & $98(44)$ & $7.8(23)$ & $0.38(21)$ & $2.33(18)$
\end{tabular}


TABLE III-continued

Control Miners : Surface workers

\begin{tabular}{l|c|c|c|c|c}
\hline $\begin{array}{c}\text { Age } \\
\text { Group }\end{array}$ & $\begin{array}{c}\text { Carotene } \\
\mu \mathrm{g} \%\end{array}$ & $\begin{array}{c}\text { Vit. A. } \\
\text { I.U. \% }\end{array}$ & $\begin{array}{c}\text { Alk. Blood } \\
\text { Phosphatase } \\
\text { Units \% }\end{array}$ & $\begin{array}{c}\text { Liver } \\
\text { Tunction } \\
\text { Test Thymol } \\
\text { Turb. } \\
\text { ml. BaSo } \\
\text { susp. }\end{array}$ & $\begin{array}{c}\text { Threshold } \\
\text { Dark } \\
\text { Adaptation } \\
\text { Log. } \mu \mu \lambda\end{array}$ \\
\hline Under 25 & - & - & - & - & - \\
$25-44$ & $112(4)$ & $115(4)$ & $9.5(2)$ & $0.4(2)$ & $2.41(4)$ \\
$45-54$ & $60(5)$ & $89(5)$ & $7.3(4)$ & $0.5(4)$ & $2.34(2)$ \\
$55-70$ & $68(7)$ & $108(7)$ & $6 \%(5)$ & $0.39(5)$ & $1.92(2)$ \\
All ages & $77(16)$ & $104(16)$ & $7.4(11)$ & $0.44(11)$ & $2.27(8)$
\end{tabular}

Normal Controls : Not miners

\begin{tabular}{l|cc|cc|cc|c} 
Under 25 & $69(2)$ & $113(2)$ & - & $0.78(1)$ & $1.52(43)^{*}$ \\
$25-44$ & $72(24)$ & $111(24)$ & $6.4(3)$ & $0.46(9)$ & $1.95(53)^{*}$ \\
$45-54$ & $93(4)$ & $116(4)$ & $6.2(1)$ & $0.44(3)$ & $2.11(24)^{*}$ \\
$55-70$ & $61(16)$ & $97(16)$ & $8.8(6)$ & $0.59(10)$ & $2.18(5)^{*}$ \\
All ages & $70(46)$ & $107(46)$ & $7.8(10)$ & $0.53(23)$ & - \\
\hline
\end{tabular}

Note: Results are expressed as the average figure in each group.

Figures in brackets $=$ number of cases.

* Threshold values in this group not concurrent with biochemical investigations.

\section{Conclusion}

Although the evidence from biochemical tests is not dramàtic it demonstrates clearly that the raised threshold for dark adaptation which is a constant feature among miners-including those suffering from nystagmus-is not due to a lack of vitamin $A$ or $D$, or to any obvious nutritional disturbance. 